\section{World Hepatitis Day — July 28, 2019}

World Hepatitis Day, observed each year on July 28, was established to raise awareness and promote understanding of viral hepatitis around the world. The theme of this year's World Hepatitis Day is "Invest in Eliminating Hepatitis," underscoring the need to increase commitment for hepatitis response. In 2015, an estimated 257 million persons were living with hepatitis $B$ and 71 million with hepatitis $\mathrm{C}$ worldwide (1).

Persons who inject drugs are at highest risk for hepatitis $C$ virus $(\mathrm{HCV})$ infection. Globally, an estimated 15.6 million persons aged 15-64 years inject drugs, 52\% of whom are $\mathrm{HCV}$-antibody positive (2). This issue of $M M W R$ features a report on the progress in the country of Georgia toward prevention and detection of HCV infection, and linkage to treatment, of persons with HCV infection who inject drugs (3). Georgia's hepatitis C elimination program, launched in 2015, was recently named the world's first Centre of Excellence in Viral Hepatitis Elimination by the European Association for the Study of the Liver International Liver Foundation. Access to hepatitis $\mathrm{C}$ testing and treatment for persons who inject drugs is critical to achieving elimination in countries where persons who inject drugs account for a significant proportion of $\mathrm{HCV}$ infection. Additional information and resources about viral hepatitis are available at https://www.cdc.gov/hepatitis.

\section{References}

1. World Health Organization. Global hepatitis report, 2017. Geneva, Switzerland: World Health Organization; 2017. https://apps.who. int/iris/bitstream/10665/255016/1/9789241565455-eng.pdf?ua=1

2. Degenhardt L, Peacock A, Colledge S, et al. Global prevalence of injecting drug use and sociodemographic characteristics and prevalence of HIV, HBV, and HCV in people who inject drugs: a multistage systematic review. Lancet Glob Health 2017;5:e1192-207. https://doi.org/10.1016/S2214-109X(17)30375-3

3. Stvilia K, Spradling PR, Asatiani A, et al. Progress in testing for and treatment of hepatitis $\mathrm{C}$ virus infection among persons who inject drugs-Georgia, 2018. MMWR Morb Mortal Wkly Rep 2019;68:637-41.

\section{Progress in Testing for and Treatment of Hepatitis C Virus Infection Among Persons Who Inject Drugs - Georgia, 2018}

Ketevan Stvilia, $\mathrm{MD}^{1}$; Philip R. Spradling, $\mathrm{MD}^{2}$; Alexander Asatiani, $\mathrm{MD}^{1}$; Maka Gogia, $\mathrm{MD}^{3}$; Khatuna Kutateladze, $\mathrm{MD}^{3}$; Maia Butsashvili, MD, PhD ${ }^{4}$; Jaba Zarkua, $\mathrm{MD}^{5}$; Tengiz Tsertsvadze, $\mathrm{MD}$, $\mathrm{PhD}^{6}$; Lali Sharvadze, $\mathrm{MD}, \mathrm{PhD}^{7}$; Maia Japaridze, $\mathrm{MD}^{8}$; Tinatin Kuchuloria, $\mathrm{MD}$, $\mathrm{PhD}^{9}$; Lia Gvinjilia, $\mathrm{MD}, \mathrm{PhD}^{9}$; Irinka Tskhomelidze, $\mathrm{MPH}^{9}$; Amiran Gamkrelidze, MD, $\mathrm{PhD}^{1}$; Irma Khonelidze, $\mathrm{MPA}^{1}$; David Sergeenko, $\mathrm{MD}, \mathrm{PhD}^{10}$; Shaun Shadaker, $\mathrm{MPH}^{2}$; Francisco Averhoff, $\mathrm{MD}^{2}$; Muazzam Nasrullah, $\mathrm{MD}, \mathrm{PhD}^{2}$

In April 2015, the country of Georgia, with a high prevalence of hepatitis $\mathrm{C}$ virus (HCV) infection $(5.4 \%$ of the adult population, approximately 150,000 persons), embarked on the world's first national elimination program $(1,2)$. Nearly $40 \%$ of these infections are attributed to injection drug use, and an estimated $2 \%$ of the adult population currently inject drugs, among the highest prevalence of injection drug use in the world $(3,4)$. Since 2006, needle and syringe programs (NSPs) have been offering HCV antibody testing to persons who inject drugs and, since 2015, referring clients with positive test results to the national treatment program. This report summarizes the results of these efforts. Following implementation of the elimination program, the number of HCV antibody

\section{INSIDE}

642 Progress Toward Poliomyelitis Eradication Nigeria, January 2018-May 2019

647 Notes from the Field: Targeted Biomonitoring for GenX and Other Per- and Polyfluoroalkyl Substances Following Detection of Drinking Water

Contamination — North Carolina, 2018

649 QuickStats

Continuing Education examination available at https://www.cdc.gov/mmwr/cme/conted_info.html\#weekly.

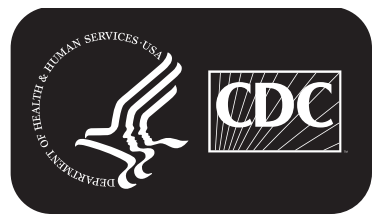

U.S. Department of Health and Human Services Centers for Disease Control and Prevention 